\title{
A Survey of Faculty Loan Policies
}

\author{
By GEORGE S. BOBINSKI
}

ONE WOULD THINK from a survey of the library literature that there was little concern over faculty loan operations among academic librarians. Only three citations are to be found in the literature published during the past thirty years, and these are short and descriptive notes on local rules and procedures. The standard works on college and university library administration by Lyle, Wilson and Tauber, and Randall also provide only brief and passing reference to this library service.

A questionnaire sent out by the Cortland State College Memorial library revealed a different attitude on the part of practicing librarians. Many admitted that this was an area of concern and a serious problem. Some felt that liberal faculty loan privileges were being abused and that circulation staffs were having a difficult time coping with inconsiderate faculty borrowers.

Another evidence of this concern may be found in the percentage of returns on the questionnaire which was sent out; with no follow up or reminder 108 out of 124 polled libraries responded. Many librarians added extensive comments to their answers and specifically requested to receive the results of the study.

The survey itself was orginally prompted by a review of the faculty loan policy at Cortland State College. It was decided to send a questionnaire to the sixty-two academic libraries belonging to the Association of Research Libraries and to sixty-two small and medium-sized libraries from primarily undergraduate institutions. The latter were selected at random
George S. Bobinski is Library Director, State University College, Cortland, New York.

from the $U . S$. Office of Education $D i$ rectory of Higher Education with almost every state being represented. Fifty-three responded from the first group and fiftyfive from the second.

The following are the questions asked in the survey with an accompanying tabulation of answers:
Answers of

53 large

research libraries
Answers of

55 small and mediumsized libraries
1. Is there a written policy statement on faculty loan regulations that can be referred to? (If possible, please enclose a copy.)

$\begin{array}{lll}37 & \text { Yes } & 20 \\ 16 & \text { No } & 35\end{array}$

2. How long do books circulate to faculty members?

\begin{tabular}{rcr}
27 & Indefinite time & 26 \\
10 & Academic year & 17 \\
15 & Semester or quarter & 10 \\
1 & One month & 1 \\
0 & Two weeks, but one & 1 \\
& semester if in own \\
\multicolumn{4}{c}{ subject area }
\end{tabular}

3. Are staff members of your institution who are not faculty accorded the same library privileges as faculty? If not, how do they differ?

$\begin{array}{lll}12 & \text { Yes } & 28 \\ 41 & \text { No } & 24\end{array}$


4. After what period of time is material recalled if wanted by another faculty member?

$\begin{array}{rcr}2 & \text { Immediately } & 20 \\ 0 & \text { One week } & 1 \\ 42 & \text { Two weeks } & 27 \\ 2 & \text { Three weeks } & 3 \\ 4 & \text { Four weeks } & 0 \\ 0 & \text { Semester } & 1 \\ 1 & \text { Depends on urgency } & 3 \\ \text { If wanted by a student? } & \\ 3 & \text { Immediately } & 21 \\ 0 & \text { One week } & 1 \\ 37 & \text { Two weeks } & 25 \\ 2 & \text { Three weeks } & 3 \\ 5 & \text { Four weeks } & 0 \\ 1 & \text { Depends on urgency } & 3\end{array}$

5. What is the faculty loan policy on:

Bound periodicals

3 Do not circulate 4

9 Regular book loan period 14

34 Short period only 26

(Overnight to one week)

2 Four weeks 0

5 Varies with 0

circumstances

0 Class period time only 5

Unbound journals

8 Do not circulate 4

5 Regular book loan period 19

$34 \quad$ Short period 24

1 Four weeks 0

4 Varies 3

0 Class period time 4

Reference books

33 Do not circulate 14

1 Regular book loan period 1

18 Short period 30

1 Four weeks 0

$0 \quad$ Class period time 7

Reserved books

1 Do not circulate 1

3 Regular book loan period 5

3 Regular book loan period 16

if own course, otherwise special arrangement

8 Regular loan period if 8 own course, otherwise like students
33 Same rule as for students 14

5 Discretion of librarian 5

0 Class period use only 1

Microprint material with portable reader

$\begin{array}{rcr}21 & \text { No } & 15 \\ 10 & \text { Yes } & 5 \\ 13 & \text { Yes with limitations } & 7 \\ 0 & \text { No policy } & 25\end{array}$

6. Are faculty subject to an overdue fine? If so, what is the fine?

$\begin{array}{rlr}52 & \text { No } & 55 \\ 1 & \text { Yes } & 0\end{array}$

7. What procedure is used to get books not returned by the specified loan period?

See text for analysis of responses to this question.

Quite understandably, more of the complex research libraries have written policy statements on faculty loan regulations than have the smaller libraries. This statement is usually found in a circulation code leaflet or in a general library handbook. It is also frequently found in a faculty handbook on the institution.

A number of librarians from both groups, but particularly from the smaller libraries, declared that they did not want to be pinned down by specific regulations in this area. Others admitted that even written rules were often not strictly observed.

There was general agreement between the two types of libraries on the time period for faculty loan. The indefinite loan, usually with a renewal requested once a year, is the most popular policy. Even where there is a specified loan period, however, faculty members can usually renew books without limitation. Thus, in practice, an indefinite loan period is prevalent almost everywhere.

Fewer of the research libraries afford the same library privileges to the nonfaculty staff than do the college libraries. One of them, in fact, provides no library privileges to this group except by special permission. In most other instances these 
staff members are given approximately the same loan privileges as the student body, although there is a tendency to be lenient on fines. Among the research libraries there are six institutions which provide a loan service to this group that is somewhere between that given to faculty and that given to students. In one case the nonfaculty staff is graded, and circulation privileges depend upon rank.

There is usually no distinction between the recall of library books for a student or for a faculty member. The smaller libraries believe in an immediate recall more than the research libraries do, but recall after two weeks is the most frequent procedure. Some small libraries give names of faculty having needed books to the student or faculty member wanting them in order that they may work out their own arrangement.

There is wide variation of practice on the loan of special materials. Many of these rules are frequently adjusted to suit the need or circumstance. For instance, among the thirty-three research libraries answering that reference books do not circulate to faculty, there would at times be exceptions to this rule. Two other observations need to be made on the responses to this question. Current issues of unbound journals normally do not circulate. The smaller libraries seem not to be, as yet, aware of the possibilities of loaning microprint materials; or perhaps they do not, as yet, have enough material of this nature to loan out.

Only one institution (a large midwestern university) imposes an overdue fine on its faculty. It is $5 \mathrm{c}$ per book per day if the material is not returned five days after the first overdue notice is sent. A small number of research libraries fine faculty members for overdue reserve books or books from a new book or browsing room collection. One mediumsized college library reported polling its faculty members on the question of fines. Surprisingly, as many voted for fines as against. However, those who were against were extremely vocal, and the idea was dropped.

The pattern of action for the return of overdue library materials is basically the same for both types of libraries. Any or all of the following may be done by the circulation head or the library director:

1. Overdue notice and/or list of overdue books

2. Personal notice or letter

3. Phone call

4. Personal contact

5. Contact department head

Upper level administrators are not often approached to act on recalcitrant faculty. Among the research libraries two institutions have their dean take action in such matters as unreturned books. Among the smaller libraries there were five instances where the dean, provost, or vice president took action, and one where the president actually stepped into the picture. There are seven research and five undergraduate libraries which work through their business offices and send bills to guilty faculty borrowers. A few libraries admitted that this does not necessarily get the book back. However, in three of these instances the pay check is withheld until the library obligation is cleared. One small library has the business office deduct the amount due from the pay check. In two libraries (one in each category) the book is repurchased from department book funds if it is not returned to the library by a specified time. One university library, after a good number of notices, sends a library page with a delivery cart to the offices of faculty members to retrieve the unreturned books.

There seems to be greater concern over faculty loan operations among the smaller libraries than the larger institutions. Many of the small libraries made extensive comments on the questionnaire.

A general feeling of hopelessness often pervades the library staff. Faculty 
have books out for such a long time (fifteen years at one college library) that they have frequently forgotten about them, or the books have become part of their office fixtures. Often the books have been loaned to colleagues or even to students that have departed from the campus. Nothing much is done except to continue sending routine notices which often are not well received or are just plainly ignored unless someone else wants the book or unless the borrower is leaving for another position. Other libraries do not give up the fight, but persist in "requests, tears, threats and even prayers." Constant "nagging" and "personal harassment" are two other techniques that seem to work for some college librarians.

Among the research libraries, where more efficient machinery and formalized rules are in operation to enforce loan time limitation, the problem arises of the great amount of staff time needed for the mechanics of recall, renewal, and overdue notices. As an example, one southern university is forced to use one staff member full time for two or three months each year to take an inventory of books loaned to faculty members.
There is general agreement that faculty members should have extended privileges on library materials. This is necessary in order that they may keep up with publications in their field, and for teaching and research purposes. But it is no excuse for keeping a book for more than one year-at this point, it appears, they should purchase it themselves. The retort that a needed book can be recalled is not always valid. Many library users in an open shelf building, it is pointed out, browse through sections pertinent to their interest and are not looking for specific titles. Even when a specific title is sought, it is perhaps needed immediately and not next week or even tomorrow. Borrowers frequently hesitate to request a recall but rather see what else, if anything, they can find on the subject.

The growing masses of students besieging academic institutions, the current trend toward greater library use by students and the concomitant inability of libraries to keep up with these demands because of budget and staff limitations, are other factors cited which should deter libraries from allowing their books to lie unused and forgotten in faculty members' bookcases.

\section{Attention: Junior College Librarians}

This yeAR the Committee on Instruction and Use of the Junior College Libraries Section of ACRL is making a collection of junior college faculty library handbooks. Please send a copy of your library's faculty handbook to Mrs. Alice B. Griffith, Librarian, Mohawk Valley Community College, 1101 Sherman Drive, Utica 3, New York for inclusion in this collection. Since the committee plans to organize and study the collection, handbooks should be mailed by January 1, 1964. Your cooperation with the committee in this project will be appreciated.-Mrs. Alice B. Griffith, Chairman, Committee on Instruction and Use. 